\title{
Os carroceiros do Recife (1870-1890): organização, insubordinação e relações de poder.
}

\author{
The carters of Recife (1870-1890): organization, insubordination \\ and power relations.
}

\section{Alessandro Filipe de Meneses Gomes*}

Resumo: O presente artigo analisa as disputas entre os carroceiros e a empresa Locomotora Pernambucana pelo transporte de cargas no Recife. Inicialmente apresenta os diferentes meios pelos quais uma mercadoria chegava à capital da província, e como se dava o seu deslocamento na área compreendida entre o cais do porto, as estações ferroviárias e as casas comerciais em geral. Em seguida, trata do fim do exclusivismo dos carroceiros na condução de carregamentos com o surgimento da Locomotora. Foi quando as carroças tradicionais passaram a concorrer com linhas de carris puxados por animais. O foco central deste texto é a rivalidade entre grupos tecnicamente distintos pelo controle de um segmento econômico específico na segunda metade do século XIX.

Palavras-chave: transporte de cargas; carroceiros; Locomotora Pernambucana.

Abstract: The following article analyzes the disputes among the carters and the Locomotora Pernambucana Company for cargo transportation in Recife. At first it introduces the different means by which a commodity approached the capital of the province, and how the same was displaced in the territory between the harbour area, the railway stations and the commercial houses in general. Afterward, it refers to the end of the carters exclusivism in driving loads with the Locomotora advent. That was the period when the traditional carts started competing with animal-drawn rails. The main point of this study is the rivalry among distinct groups of an economic segment during the second half of the nineteenth century.

Keywords: cargo transportation; carters; Locomotora Pernambucana.

* Doutor em História pela Universidade Federal de Pernambuco (UFPE). ORCID: https://orcid.org/0000-00029939-9319. E-mail: alessanddrobr@yahoo.com.br. 
U M COMPLEXO PORTUÁRIO MODERNO liga-se a sua hinterlândia por estradas de ferro e de rodagem e reúne na beira do cais não somente os aparelhos de transbordo e de tráfego interno, como também os edifícios necessários ao armazenamento, controle e administração portuária. ${ }^{1}$ Tais requisitos inexistiam, em absoluto, no porto do Recife. Em primeiro lugar, não havia separação entre a cidade como um todo e os armazéns, depósitos e trapiches (alfandegados ou não) que, muitas vezes, não ficavam na beira do cais ou sequer permitiam a atracação dos navios. Em decorrência disso, quase inexistiam equipamentos para a manipulação de cargas. As ruas sinuosas e estreitas do Bairro do Recife, quando não impossibilitavam o trânsito de carroças, dificultavam a implantação de um sistema mais eficiente de escoamento de mercadorias. Por fim, nenhuma das três ferrovias da província chegava às plataformas de embarque. A estação central da mais importante ferrovia de Pernambuco, a Estrada de Ferro do Recife ao São Francisco, ficava perto do Forte de Cinco Pontas, a cerca de um quilômetro do porto. A gare da Recife a Limoeiro, malgrado sua posição favorável no bairro portuário, bem nas imediações do Forte do Brum, não se valia do cais vizinho devido à existência de um banco de areia chamado Breguedé. E a Central de Pernambuco, cujo trajeto passava por Jaboatão e Vitória, grandes distritos produtores de açúcar e algodão, achava-se ainda mais distante do porto. ${ }^{2}$

Por conseguinte, uma mercadoria em trânsito pela capital da província passava por vários processos intermodais. Por exemplo, um produto destinado à exportação chegando ao Recife pela Estrada de Ferro do São Francisco, primeiro era baldeado para uma carroça e levado à estação de embarque, depois era manuseado por trabalhadores braçais até uma alvarenga e, finalmente, era novamente baldeado, desta vez para uma embarcação fundeada ao largo. Portanto, desde o local da produção agrícola até o porão do navio, uma mercadoria provavelmente passaria pela energia a vapor, pela tração animal, pelo trabalho de estivadores e pela pequena cabotagem. Tratava-se, na realidade, de um curioso intercâmbio entre sistemas antigos e modernos de transporte. Se a gare terminal ferroviária estivesse distante da área produtora, a mercadoria certamente já tinha sido transferida do lombo de animais para a locomotiva antes da sua chegada ao Recife. Tornando-se inviável trazê-la pela viação férrea devido ao valor do frete, ela entrava na cidade em tropas de almocreves ou por meio de barcaças, passava para uma carroça a fim de ser depositada num armazém, e, na ocasião em que fosse exportada, retornava aos carros de bois até a beira do cais, onde seria outra vez baldeada por estivadores para uma alvarenga e desta ao interior do navio. É escusado dizer que todos esses transbordos causavam danos e perdas excessivas e facilitavam o contrabando e o roubo de carga.

As mercadorias produzidas na zona sob influência do Recife chegavam ao porto de várias maneiras. Até o advento das estradas de ferro, elas vinham preferencialmente em tropas de almocreves ou em barcaças. A escolha entre uma ou outra modalidade decorria da sua própria eficácia ou da localização da área produtora. Os engenhos mais próximos dos portos fluviais ou marítimos escoavam seus produtos de exportação preferencialmente em

1 HOBSBAWM, Eric J. Sindicatos nacionais portuários. In: HOBSBAWM, Eric J. Os trabalhadores: estudos sobre a história do operariado. Rio de Janeiro: Paz e Terra, 1981. p. 242.

2 PINTO, Estevão. História de uma estrada de ferro do Nordeste: contribuição para o estudo da formação e desenvolvimento da empresa "The Great Western of Brazil Railway Company Limited" e das suas relações com a economia do Nordeste brasileiro. Rio de Janeiro: José Olympio Editora, 1949. p. 62, 91 e 105. 
barcaças. Segundo um estudioso da pequena cabotagem, a "vitória da barcaça" sobre outros tipos de embarcações à vela decorria da sua quilha em formato de prato, que tirava partido das restrições hidrográficas da região e conseguia integrar de uma só vez "os percursos marítimos e fluviais". As barcaças ainda tinham a vantagem de oferecer fretes mais baratos, exigiam pouca despesa de custeio e uma tripulação diminuta. ${ }^{3}$ Não compensando trazê-los por via aquática, os produtores enviavam-nas nas costas de animais. O engenheiro Henrique Augusto Milet elencou qual o segredo da persistência dos almocreves a despeito da implantação da rede ferroviária. Em primeiro lugar, eles participavam de todo o processo de recebimento, embalagem, entrega e venda de mercadorias; compravam as encomendas dos senhores de engenho e retornavam da viagem trazendo os sacos vazios e, eventualmente, o dinheiro da venda. Ademais, o preço negociado chegava a ser entre 40 a 60 réis mais rentável do que por um trem. ${ }^{4}$

A partir dos anos 1850, a introdução das estradas de ferro alterou a paisagem do interior da província, com seus trilhos, locomotivas e túneis, e competiu com o sistema tradicional de transporte. A segunda ferrovia do Brasil e a primeira de capital inglês, a Recife and San Francisco Railway Company começou suas atividades em 8 de fevereiro de 1858, com a abertura do trecho entre o Forte das Cinco Pontas e a cidade do Cabo. Mais tarde, os trilhos da companhia estenderam-se até Una (1862), Catende (1882) e Garanhuns (1887), cobrindo as áreas férteis da "mata úmida". Outra linha inglesa, a Great Western Railway Company, Limited, dirigiu-se na direção noroeste onde havia os distritos açucareiros da "mata seca". O tráfego da Recife a Limoeiro, título menos suntuoso da Great Western, iniciou-se, em 1881, com a inauguração da seção até Paudalho. No ano seguinte, suas linhas alcançaram Limoeiro e Nazaré, e, no final do Império, entraram em operação as seções: Nazaré-Aliança e AliançaTimbaúba. Em 1885, a grande lavoura do oeste pôde enviar seus produtos na Estrada de Ferro Central de Pernambuco. Seu projeto primitivo ia até Jaboatão, mas as lideranças locais conseguiram interiorizá-la até Caruaru. ${ }^{5}$

\section{As carroças de carga e a indisciplina}

TODAS AS MERCADORIAS que chegavam ou saíam nessas modalidades de transporte precisavam ser deslocadas localmente em carroças. A única exceção ocorria nas que vinham no lombo de animais, cujo trabalho só terminava no interior dos armazéns. Mesmo nesse caso, eram baldeadas em terra no quadro da exportação, pois do contrário não chegariam ao cais do porto. Tais veículos promoviam a ligação dos cais com as estações de trem, armazéns, trapiches e estabelecimentos em geral. Eram os grandes responsáveis pela distribuição de mercadorias por todo centro comercial. Bem antes dos congestionamentos modernos, as ruas da capital viviam repletas de carros de duas a quatro rodas puxadas por bois ou cavalos. $\mathrm{O}$ trânsito tornava-se particularmente insuportável no encontro das carroças com as tropas de almocreves. Um engenheiro fiscal do governo provincial reclamou dos "trajes incompletos dos

3 MELLO, Evaldo Cabral de. Um imenso Portugal: história e historiografia. São Paulo: Ed. 34, 2002. p. 206.

4 MILET, Henrique Augusto. A lavoura de canna de assucar. Pernambuco: Typographia do Jornal do Recife, 1881. p. 38.

5 PINTO, op. cit., 1949, p. 60-61, 85-93 e 104. 
peões" e das "filas imensas de cavalos presos uns aos outros, interrompendo constantemente o trânsito dos viandantes e demorando-se até passarem 30, 40 e mais animais que compõem os comboios". ${ }^{6}$

Na verdade, as queixas sobre o trânsito e os modos dos almocreves e carroceiros eram constantes e repetitivas. Sob o título "conveniência pública", uma folha da província propôs que os "cavalos carregados com algodão, açúcar e outros gêneros" seguissem pela ponte de Santa Isabel e deixassem a circulação dos demais veículos restrita às pontes da Boa Vista e do Recife. De acordo com o autor do artigo, a medida evitaria "a aglomeração de trens e animais, tanto naquelas vias de comunicação como nas ruas que lhe ficam em continuação". ${ }^{7}$ O mesmo problema do tráfego levou alguns moradores do Bairro do Recife a pedir na imprensa que fosse suspenso dali "o trânsito de cavalos carregados de açúcar". O jornal aproveitou a reclamação para defender a transferência dos cargueiros para vias mais adequadas, pois o tombamento recente de uma carroça quase matara um pedestre. ${ }^{8}$ Apesar das proibições, alguns carros transitavam em ruas estreitas e proibidas. $O$ condutor de um deles por pouco não vitimou um garoto na rua Direita. Conta-se que ele lamentou não o ter matado "porque o livraria de ir para [a guerra d] o Paraguai". ${ }^{9}$

A Câmara Municipal lançou mão das "posturas municipais" para controlar não só os carroceiros, como também os tropeiros que circulavam na cidade. Como normas de conduta social, as posturas visavam monitorar desde as roupas dos trabalhadores até o trote dos animais. Provavelmente, a principal delas foi a Lei n. 1.129, de 26 de junho de 1873, relativa ao "desempachamento dos lugares públicos da cidade e providência contra o abuso nas conduções de carros e animais". Assemelha-se ao atual código de trânsito no tocante à exigência de habilitação aos condutores de carros, seges, ônibus ou qualquer outro tipo de veículo, bem como às regras de estacionamento na cidade e ao limite de velocidade no perímetro urbano do Recife. ${ }^{10} \mathrm{O}$ art. 175 regulava o peso da carga para cada categoria de carroça. As carroças de quatro rodas poderiam conduzir mais de 40 arrobas, em se tratando dos carros de boi, e a metade, se o animal fosse um cavalo. Caso o veículo tivesse apenas duas rodas, o deslocamento correspondia a 2/3 da carga permitida ao de quatro rodas. $O$ condutor que ultrapassasse o limite de carga seria penalizado com uma multa de $10 \$ 000$ réis e o dobro em caso de reincidência. Ele estaria sujeito às mesmas penalidades se o veículo fosse auxiliado por escravos ou homens livres e o boi viesse "impelido à força de ferrão". 0 uso de tal instrumento só era permitido aos condutores de carros de engenho. ${ }^{11}$

A referida lei modificou-se diversas vezes para se adequar aos novos padrões de pesos e medidas e aos interesses dos proprietários de carroças. $O$ art. $8^{\circ}$ da Lei n. 1.178 , de 5 de junho de 1875, substituiu a arroba pelo quilo e aumentou o peso correspondente a cada veículo. Se antes uma carroça de quatro rodas e movida por um boi poderia conduzir o equivalente a

6 ARQUIVO PÚBLICO ESTADUAL JORDÃO EMERENCIANO (doravante APEJE). Relatório das ocorrências havidas durante o anno de 1875 em relação a Locomotora Pernambucana. Recife: Fundo; Companhias Diversas D-II; natureza: manuscrito, fl. 437, 1875.

7 Conveniência pública. Jornal do Recife, Recife, n. 250, a. VII, p. 1, c. 6, 27 out. 1865.

8 Merecem ser attendidos. Jornal do Recife, Recife, n. 12, a. X, p. 2, c. 2, 16 jan. 1869.

9 Rua Direita. Jornal do Recife, Recife, n. 26, a. X, p. 3, c. 2, 1 fev. 1868.

10 SOUZA, Maria Angela de Almeida. Posturas do Recife Imperial. 2002. Tese (Doutorado em História) Universidade Federal de Pernambuco, Recife, 2002.

11 PERNAMBUCO. Lei n. 1.129, de 26 de junho de 1873. Leis Provinciais do anno de 1873. Pernambuco: Typographia de M. F. de Faria \& Filhos, 1873. p. 129. 
$600 \mathrm{~kg}$ (40 arrobas), agora levaria mais de $750 \mathrm{~kg}$ (10 sacos de açúcar). Se ela fosse puxada por um cavalo, o limite passaria dos $300 \mathrm{~kg}$ (20 arrobas) para mais de $525 \mathrm{~kg}$ (sete sacos do mesmo produto). ${ }^{12} \mathrm{Em} \mathrm{1879}$, uma proposta de postura adicional pretendia aumentar ainda mais o volume da carga. As carroças puxadas por um boi teriam a carga máxima de 12 sacos de açúcar. Já as carroças contendo dois bois poderiam conter até 16 sacos. Esses números seriam 10 e 15 sacos respectivamente, caso o animal fosse um cavalo. O valor da multa em caso de infração permaneceria o mesmo, isto é, $10 \$ 000$ réis. ${ }^{13}$

Mas a Lei n. 1.410, de 12 de maio de 1879, não chegou a ser tão dura com os animais. $\mathrm{O}$ art. $1^{\circ}$ definia que "nenhum carro ou carroça de quatro rodas, destinado à condução de gêneros" poderia transportar mais de 12 sacos tendo apenas dois bois. Já o art. $2^{\circ}$ estabeleceu o limite máximo de dez sacos de açúcar para os carros com duas rodas e apenas um cavalo; e de 18 sacos para os que tivessem a mesma quantidade de rodas e fossem puxados por dois cavalos. Embora bem definidas na teoria, esta e outras tantas leis do Império foram construídas "para inglês ver". Uma "Publicação Solicitada" do Jornal do Recife, depois de transcrever a legislação em vigor, chamou a atenção das autoridades de serem vistos "constantemente pelas ruas desta cidade carros de quatro rodas puxados por um só boi, transportando 14 e mais sacos de açúcar; outros de duas rodas puxados por um só cavalo conduzindo número muito superior ao determinado". ${ }^{14}$

As posturas foram ineficazes no combate ao transporte excessivo de cargas e ao castigo físico dos animais. Desde 1855, uma postura adicional proibia "todo e qualquer cocheiro e condutor de carroça, pipa d'água etc. maltratar os animais com castigos bárbaros e imoderados". Entretanto, o que se via na prática era "cavalos e bois magros e chagados" carregando "peso superior a 100 arrobas". Como os animais não tinham força proporcional, "o selvagem carroceiro" abusava do uso do pau e ferrão a tal ponto que chegava a matálos. Em 1874, a Secretaria de Polícia instituiu um regulamento exigindo que os boleeiros e carroceiros tivessem matrícula na instituição e se submetessem a uma prova de habilidade. Os condutores também teriam que anexar uma placa contendo o número do veículo. $O$ art. 21 dizia que "nenhum boleeiro ou carroceiro poderá castigar imoderadamente os animais com que trabalharem". Mas, assim que o regulamento entrou em vigor, "um pobre descendente de Ápis, magro, faminto e cansado da vida que levava sob o ferrão de um desalmado filho da Galiza" parou extenuado no Cais do Apolo. O "desalmado condutor" fustigou em vão o animal e após Ihe tirar a canga, o boi jogou-se no rio. No ano seguinte, outro boi parou ferido na rua da Aurora. Seu condutor colocou um feixe de cordas sobre a placa de identificação do veículo para se preservar da postura que proibia de "andarem em serviço animais feridos". Sob o título "Matéria velha", uma folha narrou o espancamento de um boi por um grupo de "desalmados carroceiros" que tentaram forçá-lo a prosseguir o transporte de 15 sacos de açúcar. Como o animal manteve-se inerte, retiraram a carreta do caminho e deixaram "a pobre vítima de sua selvageria estendida no chão". 15

12 PERNAMBUCO. Lei n. 1.178, de 5 de junho de 1875. Leis Provinciais do anno de 1875. Pernambuco: Typographia de M. F. de Faria \& Filhos, 1875. p. 33.

13 Câmara Municipal do Recife. Jornal do Recife, Recife, n. 41, a. XXII, p. 1, c. 2, 19 fev. 1879.

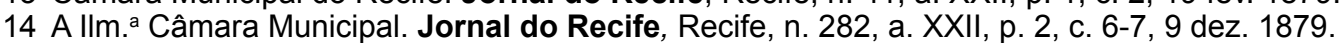

15 A ordem dos fatos e das citações é a seguinte: Câmara Municipal do Recife. Jornal do Recife, Recife, n. 24, a. XII, p. 2, c. 5-6, 30 e 31 jan. 1870; Máo tracto aos animaes. Jornal do Recife, Recife, n. 16, a. XII, p. 1, c. 2,

21 jan. 1870; Regulamento. Jornal do Recife, Recife, n. 21, a. XVII, p. 1, c. 2-4, 27 jan. 1874; Suicídio bovino. 
Sem um concorrente direto e estando a circulação de mercadorias totalmente dependente das carroças, muitos carroceiros contavam com a proteção do comércio, às vezes em seu próprio prejuízo. Em 1861, Souza Reis elevou o tom na Assembleia Provincial ao dizer que o "transporte dos gêneros das Cinco Pontas para o Recife era pessimamente feito, e que muitas eram as queixas da falta dos gêneros transportados". Para o deputado, a culpa dos saques era dos carroceiros que não tinham "nenhuma responsabilidade" com a segurança da carga. ${ }^{16}$ Em 1869, o editorial do Diário de Pernambuco endereçou ao ministro da Agricultura uma série de artigos em que reivindicava providências urgentes contra os transtornos experimentados pelos principais gêneros de exportação até a estação de embarque. Em primeiro lugar, eles sofriam duas operações de carga e descarga nos vagões da ferrovia até a gare de Cinco Pontas, em seguida passavam por mais duas baldeações em carroças até o cais do porto. Nesse percurso, as mercadorias sofriam danos devido aos excessivos transbordos e acabavam sendo expostas à "má fé dos condutores de carroças, que muitas vezes se não pejam de violar os volumes que lhes são entregues". ${ }^{17}$

Não sabemos se houve desinteresse da companhia ou se a eterna indecisão do governo imperial atrapalhou seus planos, mas a principal ferrovia de Pernambuco, a Recife a São Francisco, não conseguiu prolongar seus ramais até o cais. É certo que a companhia apresentou, na década de 1860, vários projetos nesse sentido, mediante garantias de juros, subsídios governamentais ou uma permissão especial para substituir trechos contratados. Mas o governo imperial foi inflexível quanto à concessão de novas vantagens e não se decidiu entre o prolongamento da linha férrea até o Bairro do Recife ou ao Cais do Ramos, no bairro de São José. Na verdade, enquanto não fosse solucionada a questão técnica do porto, não haveria uma solução do problema. A extensão dos ramais até o bairro portuário exigia a construção de uma ponte sobre o rio Capibaribe e a desapropriação de imóveis públicos e particulares. Se a gare permanecesse em São José, somente obras de dragagem na praia de Santa Rita possibilitariam a aproximação dos navios da estação de Cinco Pontas. Essa proposta chegou a ser levada parcialmente a efeito sob o comando do engenheiro francês Victor Fournié. Mas, como não solucionou o problema, o transporte de cargas permaneceu dependente dos carroceiros. ${ }^{18}$

\section{A concorrência dos carris}

Os CARROCEIROS apenas se sentiram ameaçados diante da concessão originalmente dada a Belarmino do Rego Barros, José Joaquim da Silva Antunes e José da Silva Loyo para instalarem um sistema de transporte de carga sobre trilhos. Os empresários adquiriram a concessão

Jornal do Recife, Recife, n. 60, a. XVII, p. 4, c. 2, 14 mar. 1874; Animal chagado. Jornal do Recife, Recife, n. 5, a. XVIII, p. 1, c. 3, 8 jan. 1875; Matéria velha. Jornal do Recife, Recife, n. 25, a. XVIII, p. 1, c. 5, 1 fev. 1875.

16 Diário de Pernambuco, Recife, n. 124, a. 37. p. 1, c. 6, 31 maio 1861.

17 O Sr. Ministro da Agricultura e a estrada de ferro do Recife a S. Francisco: prolongamento para o centro da cidade. Diário de Pernambuco, Recife, n. 288, a. XLV, p. 2, c. 1-3, 17 dez. 1869.

18 Diário de Pernambuco. Recife, n. 165, a. XLI, p. 2, c. 2-3, 21 jul. 1865; Jornal do Recife, Recife, n. 70, a. VIII, p. 1, c. 2, 26 mar. 1866; GALVÃO, Manoel da Cunha. Notícia sobre as estradas de ferro do Brasil. Rio de Janeiro: Typographia do Diário do Rio de Janeiro, 1869. p. 257-267. BRASIL, Governo do (1875-1878: Almeida). Relatório apresentado à Assembleia Geral Legislativa na primeira sessão da décima sexta legislatura pelo ministro e secretário de Estado dos Negócios da Agricultura, Commercio e Obras Públicas, Thomaz José Coelho de Almeida. Rio de Janeiro: Typographia Perseverança, 1877. p. 313. 
apresentando uma proposta diferencial. Enquanto os demais interessados restringiram o raio de atuação de suas empresas à zona portuária, a proposta vencedora propôs estendê-lo até a freguesia de Afogados e a Passagem Madalena. Na verdade, os concessionários não visavam assumir o empreendimento. Eles transferiram a concessão de 25 anos para o Banco Industrial e Mercantil do Rio de Janeiro que, por sua vez, constituiu a firma social Teixeira, Chaves \& Cia., um consórcio formado pela mesma unidade bancária e os empresários Antônio Augusto Teixeira e Tito Chaves Barcelos. ${ }^{19}$ Os novos proprietários instalaram cerca de $8 \mathrm{~km}$ de linhas férreas entre o cais da Companhia Pernambucana e a estação de Cinco Pontas, sendo a maior parte dos ramais alocados nas artérias do Bairro do Recife. ${ }^{20} \mathrm{Em} 10$ de agosto de 1874, a Locomotora Pernambucana iniciou suas operações com o transporte de "trinta e tantos sacos de açúcar da marca Sibiró Grande, consignados à Correia \& Cia.". ${ }^{21}$

Prometendo o transporte rápido de mercadorias e a preços mais módicos, a companhia experimentou a animosidade dos donos de carroças, inicialmente nas páginas do jornal A Província e, em seguida, pelas ruas do Recife. Em menos de um mês, diversas agulhas e trilhos da linha férrea foram misteriosamente arrancadas. Um homem chegou a ser acusado de cometer tal "brincadeira", porém acabou sendo liberado pelo inspetor de polícia. A brincadeira continuou nos meses seguintes e a Locomotora ofereceu um prêmio de 200 réis a quem delatasse o infrator "com todas as provas". ${ }^{22} \mathrm{~A}$ hostilidade agravou-se ainda mais quando entrou em discussão uma postura municipal estipulando o limite máximo de oito sacos de açúcar para cada carroça, a pretexto de que um número maior de sacos superava a capacidade física dos animais. A regulamentação da Câmara Municipal também visava o sistema de amortização das carroças em razão dos danos causados pela trepidação sobre o calçamento da cidade. Ainda que as posturas dirigidas aos carroceiros fossem anteriores à existência da Locomotora, a interferência municipal no modelo tradicional do transporte de cargas arregimentou diversos carroceiros contra "a prepotência dos patoteiros", de quererem impor "o arbítrio e a violência da carga inferior à lotação de suas carroças". Diante da ameaça de perturbação da ordem pública, as autoridades instituídas imediatamente revogaram o ato e permitiram que as carroças fretassem até "16 sacos de açúcar e mais gêneros e volumes, na razão que comportarem as respectivas lotações". ${ }^{23}$

A partir daí, os proprietários carroceiros organizaram uma "associação", ou melhor, "outra espécie de empresa, representada por diversos possuidores, que se auxiliaram reciprocamente" para "empecer a marcha da Locomotora", ora dirigindo suas carroças sobre a linha de carris, ora "se prostrando nas portas de carga e descarga dos armazéns, de modo a proibir o trânsito dos carros da empresa". Se a Locomotora prometia maior celeridade no

19 PERNAMBUCO, Governo de. (1874-1876: Lucena). Falla com que o Exm. ${ }^{\circ}$ Sr. Commendador Henrique Pereira de Lucena abrio a sessão da Assembléa Legislativa Provincial de Pernambuco em 1 de março de 1874. Recife: Typ. de M. Figueiroa de F. \& Filhos, 1874. p. 59.

20 APEJE. Relatório da Locomotora Pernambucana (1874). Recife: Fundo; Companhias Diversas D-II; natureza: manuscrito, fls. 424-425 v e anteriores, 1874.

21 APEJE. Ofício do engenheiro Crisólito Ferreira de Castro Chaves dirigido ao presidente da província Henrique Pereira de Lucena. Recife, 11 de agosto de 1874. Recife: Fundo; Companhias Diversas D-II; natureza: manuscrito, fl. 414, 11 ago. 1874.

22 Locomotora. Jornal do Recife, Recife, a. XVII, n. 207, p. 1, c. 3, 14 set. 1874; Perseguição à Locomotora. Jornal do Recife, Recife, n. 284, p. 1, c. 4-5, 14 dez. 1874; Jornal do Recife, Recife, n² 297, p. 3, c. 6, 30 dez. 1874; Jornal do Recife, Recife, $n^{\circ} 3$, p. 3, c. 5, 5 jan. 1875.

23 A Locomotora Pernambucana. A Província, Recife, n. 452, a. III, p. 3, c. 3-4, 26 nov. 1874; Revolução e mais revolução. A Província, Recife, n. 465, a. III, p. 1, c. 4, 12 dez. 1874. 
transporte de carregamentos, eles promoviam "todos os embaraços de modo a destruir tais vantagens, e chamar o descrédito para ela". ${ }^{24} \mathrm{~A}$ ação dos carroceiros ia desde o boicote dos trilhos da empresa até a marginalização dos seus funcionários. Os alvos preferidos deles eram os cocheiros e antigos carroceiros. Um deles, de nome Viana, foi comparado a Judas por deixar os antigos companheiros para se tornar empregado da Locomotora. ${ }^{25}$

$\mathrm{Na}$ maioria das vezes, apenas com a intervenção direta da Presidência provincial, da Câmara Municipal e do corpo policial era possível manter seus carros em operação. A municipalidade elaborou uma postura destinada a impedir a obstrução dos trilhos, o que ocorria não só pela ação direta dos carroceiros, como pelas bancas de vendedores ambulantes e bêbados da cidade. Porém, tão logo diminuía a participação do poder público, voltava o clima de provocação. Os próprios fiscais e integrantes da polícia, mesmo topando com "algum carroceiro impertinente e provocador", deixavam os condutores entregues à própria sorte. ${ }^{26}$ O que estava por trás da sabotagem não eram tanto os carroceiros em si, os quais seriam facilmente excluídos do ramo de carga "aos pontapés", e sim os "proprietários [de carroças] e homens tão respeitáveis" quanto os que estavam à frente da Locomotora e que estavam dispostos "a fazer valer os seus direitos por todos os meios". ${ }^{27}$

\section{Carregadores e carroceiros}

O ÚLTIMO TRECHO ILUSTRA a existência de clivagens no seio do sistema carroçável que, aliás, foram observadas por dois estudos pioneiros. O primeiro deles é a dissertação de Ana Maria Moura sobre os cocheiros e carroceiros da cidade do Rio de Janeiro. Ela dividiu seu corte temporal em duas fases. Na primeira delas, que vai de 1850 a 1870, predominou os carroceiros de frete, cuja posse da ferramenta de trabalho impediu, na sua visão, a formação de relações de solidariedade de grupo e tampouco uma consciência de classe. Já na segunda, situada entre 1870 e 1890, surgiram os cocheiros de aluguel que, por serem trabalhadores assalariados das empresas de carris, possuíam relações de companheirismo mais fortes do que os carroceiros. Embora admitindo certa diversificação no emprego da carroça e do carril, a autora não estabeleceu nenhum tipo de hierarquia ou estratificação no interior dessas categorias. Pergunta-se: os carroceiros do lixo ocupavam o mesmo espaço social dos carroceiros de mudança? Os cocheiros das empresas de bondes partilhavam das mesmas demandas dos boleeiros atuantes em cocheiras públicas? Todas as peculiaridades resumem-se aqui ao trabalho autônomo ou assalariado. ${ }^{28}$

O historiador Paulo Terra inicialmente analisou a formação do mercado de trabalho no Rio de Janeiro a partir das atividades de carregadores, carroceiros e cocheiros, entre 1823 e 1870. Seu objeto foi a transição do trabalho realizado por carregadores negros para

24 APEJE. Relatório [do engenheiro fiscal da Locomotora Pernambucana, Crisólito Ferreira de Castro Chaves]. Recife, 20 de fevereiro de 1880. Recife: Fundo; Companhias Diversas D-Il; natureza: manuscrito, fls. 483-483v, 20 fev. 1880.

25 Vi-Anna na Locomotora. A Província, Recife, n. 374, a. II, p. 4, c. 1, 22 ago. 1874.

26 APEJE. Gabinete do Fiscal da Locomotora. Recife, 16 de novembro de 1878. Recife: Fundo; Companhias Diversas D-II; natureza: manuscrito, fl. 471, 1878.

27 A Locomotora e a polícia. Jornal do Recife, Recife, n. 12, a. XXIII, p. 2, c. 4-5, 16 jan. 1880.

28 MOURA, Ana Maria da Silva. Os cocheiros e carroceiros: homens livres no Rio de senhores e escravos. São Paulo: Hucitec, 1988. 
o sistema carroçável, destacando as relações de conflito e solidariedade entre trabalhadores livres, libertos e escravos que, segundo ele, se caracterizaram por relações horizontais e segmentação. Dando continuidade a essa pesquisa, ele estudou a questão da cidadania entre nós através das práticas de organização e mobilização dos cocheiros e carroceiros na mesma cidade, de 1870 a 1906. Fazendo uma crítica do trabalho de Ana Moura, ele chamou a atenção para a existência de uma classe intermediária entre o trabalhador-proprietário autônomo e o assalariado. Era o caso dos condutores que nem trabalhavam para empresas de carris e nem eram donos dos veículos. Ele cita o exemplo de um carroceiro atuante em São Paulo que alugou uma carroça e duas bestas ao próprio irmão com o intuito de obtê-las no futuro. Mas o autor limita-se a essa observação preliminar. Seu foco são as atividades grevistas, as lutas por direitos e as associações sindicais e mutualistas. ${ }^{29}$

$\mathrm{Na}$ realidade, os dois autores falaram dos carroceiros de modo um tanto genérico, fizeram o mesmo com a categoria dos cocheiros e não analisaram o transporte carroçável em si e suas variadas combinações. A palavra carroceiro dizia respeito tão somente a quem tinha uma atividade econômica ligada a um veículo chamado carroça. O que determinava o papel de cada agente era a variante formada pelo carro (de duas ou mais rodas), pela energia animal (boi ou cavalo), pelo condutor (dono ou não do veículo), pela cocheira (pública ou privada), pela qualidade da carga transportada (pessoas, mercadorias ou gêneros diversos), pela regularidade da atividade (esporádica ou constante), pela cobertura espacial (urbana, rural ou ambas), pela distância do trajeto e pelo perfil do trabalhador. A título de exemplo, um grupo de carroceiros portugueses, que reagiu ao ataque de salteadores na viagem de retorno ao Recife vindos da cidade de Paudalho, praticava uma atividade similar à dos almocreves, guardando, portanto, pouca ligação com os carroceiros urbanos. ${ }^{30}$ Por conseguinte, o status socioeconômico, os espaços de atuação, as negociações e o poder de enfrentamento de cada grupo variavam conforme a posição na ordem social.

Por esses motivos, optamos por analisar unicamente a categoria dos carroceiros de carga atuantes em um espaço geográfico específico. Vale aqui destacar que os condutores dessas carroças não devem ser confundidos com os demais trabalhadores do gênero. Havia uma enorme diferença entre os carroceiros que recolhiam o lixo da cidade, realizavam trabalhos esporádicos ou conduziam passageiros dos que transportavam produtos de importação e exportação. Como exerciam uma atividade vital ao fluxo de mercadorias, os carroceiros de carga, sobretudo os ligados aos negócios do porto, resistiam de modo mais eficaz contra as tentativas de controle da categoria ou a possíveis concorrentes. Veremos adiante que mais do que simples trabalhadores autônomos, eles estavam perfeitamente organizados antes do surgimento da Locomotora devido a uma experiência do tipo empresarial que Ihes permitia disputar em igualdade de direitos.

Antes de tudo, é bom destacar que o serviço carroçável em foco além de complexo não estava ao alcance de todos. O interessado no ramo precisava adquirir ou alugar o carro e a energia animal, destiná-los um local de guarda ou cocheira e definir um condutor, que

29 TERRA, Paulo Cruz. Tudo que transporta e carrega é negro? Carregadores, cocheiros e carroceiros no Rio de Janeiro (1824-1870). Dissertação (Mestrado em História) - Universidade Federal Fluminense, 2007; idem. Cidadania e trabalhadores: cocheiros e carroceiros no Rio de Janeiro (1870-1906). Rio de Janeiro: Arquivo Geral da Cidade do Rio de Janeiro, 2013.

30 Assalto. Jornal do Recife, Recife, a. XI, n. 196, p. 1, c. 4, 27 ago. 1869. 
poderia ser ele mesmo ou um terceiro. Alguns carroceiros prósperos tinham seus próprios escravos ou contratavam trabalhadores livres. A atividade estava sujeita ao pagamento de impostos por cada carro e uma taxa relativa à indústria e profissão. Seu exercício abarcava uma imbricada rede de relações com agentes ferroviários e portuários, agricultores, senhores de engenho, carregadores, consignatários, comerciantes, armazenários e seus respectivos correspondentes. Quem solicitava uma carroça firmava com eles uma relação de confiança mútua. A responsabilidade passava pela recepção, segurança, proteção (inclusive contra o mau tempo) e entrega do carregamento ao receptor final. Se por algum motivo a mercadoria não chegasse no prazo, o carroceiro responsável cuidava da armazenagem provisória. Quem dominasse todas essas etapas poderia abandonar o transporte propriamente dito e se tornar senhor do próprio negócio.

Portanto, o exercício da profissão possibilitava alguma mobilidade social, o que pode explicar o predomínio de homens livres no segmento, sobretudo portugueses. Decerto alguns deles chegaram ao Brasil com algum capital que lhes facultava a compra do primeiro veículo. O discurso de Cunha de Figueiredo na Assembleia Legislativa Provincial denota o quanto o ofício era particularmente atrativo aos estrangeiros:

A colonização estrangeira, máxime da Europa (apoiados), os europeus nada valem para nós para a agricultura, quando chegam aqui uns querem ser comerciantes, de que já temos muita abundância, outros querem ser carroceiros, outros querem escovar botas (continua a hilaridade), mas nenhum, Sr. Presidente, quer ir sofrer a amargura dos trabalhos agrícolas (apoiados) ${ }^{31}$

Grosso modo, o sistema de carga atravessou três fases. A primeira coincide com o início das operações da ferrovia do São Francisco dentro de um quadro de "modernização incompleta". A falta de conexão da ferrovia com o porto atraiu alguns carroceiros avulsos para o transporte de carregamentos. A segunda é fruto da aceleração das atividades econômicas da província devido a uma conjugação de fatores. O capitalismo internacional experimentou um processo de expansão e desenvolvimento. A liberação do capital com o fim do tráfico negreiro permitiu sua aplicação em obras de infraestrutura e serviços urbanos. A navegação subvencionada e a liberação da cabotagem aproximaram ainda mais o porto do Recife dos grandes centros comerciais. A economia algodoeira atravessou uma fase de prosperidade em razão da Guerra Civil Americana. E a indústria açucareira enfrentou a concorrência do açúcar da cana e do de beterraba da Europa com a ampliação da fronteira agrícola. ${ }^{32} \mathrm{O}$ transporte carroçável, outrora um tanto marginal, tornou-se cada vez mais indispensável aos negócios da cidade e atraiu a cobiça de estabelecimentos comerciais e industriais, que passaram a adquirir seus próprios veículos e trabalhadores e a competir com os carroceiros tradicionais. Por fim, o surgimento de novas empresas, sob a lei das sociedades anônimas, ameaçou os transportes tradicionais em geral e o de carga em particular.

31 ANNAES da Assemblea Provincial de Pernambuco. Anno de 1876. Pernambuco: Typ. do M. de Figueiroa de Faria \& Filhos, 1876. p. 496.

32 EISENBERG, Peter. Modernização sem mudança: a indústria açucareira em Pernambuco, 1840-1910. Rio de Janeiro: Paz e Terra; Campinas: Unicamp, 1977; SINGER, Paul. Desenvolvimento econômico e evolução urbana: análise da evolução econômica de São Paulo, Blumenau, Porto Alegre, Belo Horizonte e Recife. $2^{\mathrm{a}}$ ed. São Paulo: Editora Nacional, 1977. 
A referida lei tornou obsoletas as empresas de caráter individual, ao possibilitar a associação de capitais e a expansão da produtividade. Seu impacto foi sentido de várias maneiras. A Companhia do Beberibe comprometeu boa parte do abastecimento realizado em canoas e carroceiros de pipas d'água. A Recife Drainage Company transformou o modo com que as carroças recolhiam o lixo a cidade. Mas a repercussão maior se deu nos transportes urbanos. A busca de grandes dividendos atraiu investidores nacionais e estrangeiros para a composição de companhias de trens e carris. Em 1867, a Brazilian Street Railway Company instalou trilhos ligando a capital da província ao arrabalde de Apipucos. Suas locomotivas de pequeno porte, conhecidas entre nós pela corruptela "maxambomba" (machine pump), levavam passageiros, cargas e bagagens. A Companhia de Trilhos Urbanos do Recife a Olinda entrou em operação em 1870, com vagões de carga, malas e pessoas e, dois anos depois, a Companhia Ferro Carril, antiga Pernambuco Street Railway, inaugurou um serviço exclusivo de passageiros com carris de ferro puxados por burros. A aparição de cada uma dessas empresas teve implicações diretas nos meios transportes preexistentes. ${ }^{33}$

No tocante ao transporte de carga, o primeiro protesto contra os carris contabilizou mais de 700 carroças matriculadas no Consulado Provincial, em 1871. Estimava-se que uma empresa privada empregaria no mesmo serviço entre 40 e 50 carros, de modo que ambos seriam incapazes de acompanhá-la no preço e ver-se-iam obrigados a abandoná-lo. Não se tratava de exagero do articulista do Diário de Pernambuco. Em menos de um ano do funcionamento da Locomotora, conforme o editorial de A Província, "cerca de 300 famílias, cujos chefes tinham carroças e animais empregados no transporte de gêneros entre as ruas desta cidade, foram forçados a vender, de um momento para outro e por baixo preço, esses veículos e seus motores". ${ }^{34}$

É escusado aduzir que só os mais prósperos e politicamente fortes resistiram nessa atividade durante a vigência da empresa. Esse grupo privilegiado chamava a si mesmo de "carregador". O termo certamente foi tomado de empréstimo da realidade portuária. Ele tanto dizia respeito ao responsável pelo fretamento do navio como aos agentes exportadores de mercadorias. O carregador sobre rodas era todo aquele que possuía a carroça, sendo ele carroceiro ou não. Com efeito, a palavra significava cada vez mais o proprietário empregador do que quem acumulava a posse com a condução da carroça. Esse grupo estava no limite da competitividade existente no interior do próprio serviço carroçável, no qual o dono de um carro concorria com os possuidores de várias unidades e o carroceiro avulso sofria um processo de proletarização. Na prática, a Locomotora apenas potencializou a destituição dos instrumentos de trabalho dos carroceiros pobres, tentou submetê-los a outra lógica de trabalho, e ameaçou a hegemonia das carroças como um todo. Só restou aos carregadores remanescentes,

33 JUCÁ, Gisafran Nazareno Mota. A implantação de serviços urbanos no Recife: o caso da Companhia do Beberibe (1838-1912). 1979. Dissertação (Mestrado em História) - Universidade Federal de Pernambuco, 1979; MENEZES, José Luiz Mota; ARAÚJO, Hamilton Francisco de; CHAMIXAES, José Castelo Branco. Águas do Prata: a Companhia do Beberibe e a história do saneamento de Pernambuco, 1838-1912. Recife: Compesa, 1991; DUARTE, José Lins. Recife no tempo da Maxambomba (1867-1889): o primeiro trem urbano do Brasil. 2005. Dissertação (Mestrado em História) - Universidade Federal de Pernambuco, 2005; ZAIDAN, Noemia Maria. O Recife nos trilhos dos bondes de burro (1871-1914). 1991. Dissertação (Mestrado em Desenvolvimento Urbano) - Universidade Federal de Pernambuco, 1991.

34 Aos Exm. ${ }^{\circ S}$ Srs. Deputados provinciaes. Diário de Pernambuco, Recife, n. 62, p. 3, c. 1, 16 mar. 1871. Eleição de deputados provinciaes. A Província, Recife, n. 726, p. 1, c. 1-2, 10 nov. 1875. 
chamados genericamente de carroceiros, a organização dos seus trabalhadores contra a tentativa de monopolização da empresa.

$\mathrm{Na}$ realidade, a existência de relações hierárquicas no interior da atividade carroçável antecede à Locomotora. Ela se manifestou durante a apresentação das primeiras propostas para a instalação de carris entre o porto e a gare ferroviária. Nessa época, uma publicação dirigida aos deputados provinciais afirmou que tal privilégio implicaria na morte da "pequena indústria de diversas pessoas que se incumbem de tal serviço". Na visão do arguidor, o privilégio traria o inconveniente do monopólio e teria consequências nas receitas municipais em virtude da perda dos impostos pagos pelas carroças. Um representante anônimo dos peticionários contra-argumentou que o novo sistema, ao contrário do antecedente, preservaria o calçamento e a limpeza da cidade, a receita pública não sofreria diminuição, uma vez que os carros da empresa seriam tributados e o público poderia escolher entre os carroceiros ou a linha de carris. A forma genérica com que tratara a categoria incitou uma tréplica reveladora: "Não tem razão o respondente, taxando-nos de carroceiros, porque não é carroceiro quem tem carroças e animais, e que tem seu capital empregado; carroceiro é aquele que serve de guia ao animal que conduz a carroça". ${ }^{35}$

Em suma, os carroceiros e os proprietários dos instrumentos de trabalho não eram necessariamente as mesmas pessoas. O problema é que não sabemos nada sobre a classe dos carregadores. Não há uma só palavra a seu respeito nos textos de Ana Moura e Paulo Terra. O último limitou-se a dizer, baseando-se em apenas uma evidência, tirada do livro de Elciene Azevedo, ${ }^{36}$ que trabalhadores autônomos alugavam carroças a terceiros. Ocorre que a mencionada fonte dá a entender que a propriedade da carroça se mantinha no âmbito dos carroceiros. Mas um artigo do Jornal do Recife narrou uma ação repressiva da polícia para beneficiar a Locomotora e a ameaça sofrida pelo "filho de um senhor de engenho, o qual pugnava pelos seus direitos, como proprietário de várias carroças, cujo trânsito estava sendo interrompido sem razão plausível". O mesmo autor da matéria afirmou que os "mantenedores da ordem pública" só não conseguiram perturbá-la com sua violência graças à "prudência evangélica de que se tem revestido os carroceiros, obedecendo às recomendações expressas e positivas dos proprietários das carroças". ${ }^{37}$

\section{Organização e estratégia}

NA VERDADE, A ORGANIZAÇÃo da atividade carroçável atuante na estação de Cinco Pontas e na zona portuária é anterior aos carris e indica as relações de força existentes no segmento. Em 1864, O Liberal criticou a intenção dos "principais funcionários" da Recife ao São Francisco de quererem conduzir o açúcar da ferrovia aos armazéns do Bairro do Recife, de sorte que o carreto e o frete fossem pagos na estação. Com isso, os agricultores seriam prejudicados com o fim da concorrência dos carros particulares e da falta de controle da empresa sobre

35 A ordem dos fatos e das citações é a seguinte: Diário de Pernambuco, Recife, a. XLVII, n. 58, 59 e 62, p. 2 , c. 3 ; p. 2, c. 3 e p. 3, c. $1 ; 11,13$ e 16 mar. 1871.

36 AZEVEDO, Elciene. A metrópole às avessas: cocheiros e carroceiros no processo de invenção da "raça paulista". In: AZEVEDO, Elciene; CANO, Jefferson; CUNHA, Maria Clementina Pereira; CHALHOUB, Sidney (org.) Trabalhadores na cidade: cotidiano e cultura no Rio de Janeiro e em São Paulo, séculos XIX e XX. Campinas: Editora da Unicamp, 2009.

37 A Locomotora e a polícia. Jornal do Recife, Recife, n. 14, a. XXIII, p. 2, c. 4, 18 jan. 1880. 
a segurança da carga. O articulista ironizou a capacidade administrativa de seu idealizador, Francisco Maria Duprat, ao recordar de suas experiências malogradas no setor da edificação, tecelagem do algodão e bancos de ostras. ${ }^{38}$ Vale dizer que os funcionários em questão não queriam suplantar as carroças, e sim lucrar com as cargas em trânsito na cidade naqueles anos economicamente prósperos para o algodão. Seu superintendente, Godfrey Oates Mann, firmou uma sociedade com Francisco Duprat, cujo parente de nome Augusto trabalhava como chefe de tráfego. ${ }^{39}$

No mesmo ano, surgiu a Agência Duprat. A empresa declarava-se "protetora" dos carroceiros avulsos e atuava fisicamente nos armazéns da estação e no bairro portuário, tendo a seu dispor "carros e carroças matriculadas na repartição competente, pertencendo a numerosos carroceiros nacionais e estrangeiros, com o concurso dos quais mandava levar diariamente até o meio-dia das Cinco Pontas ao Recife em comboio especial". Ela implantou uma "organização de serviço e divisão do trabalho" a partir da safra de 1865-66. Os pedidos de frete ocorriam no dia anterior ou horas antes da remessa. As mercadorias seguiam acompanhadas com o conhecimento de carga e o condutor se responsabilizava pelos sacos vazios. A agência de "transportes acelerados", cujo administrador também era editor do periódico O Brasil Agrícola, dizia em seu anúncio que não queria "monopolizar e cumular o benefício do agente e carregador direto". Sua remuneração limitava-se a uma "comissão por volume" dando a "ganhar ao grande número de carroceiros que ele ocupa durante a safra, o resto do preço que recebe por cada volume". ${ }^{40}$

Esse sistema de organização pareceu ter agradado a gregos e troianos. A agência e os funcionários da Recife ao São Francisco recebiam um percentual sobre as mercadorias chegadas ou saídas na gare, e os carregadores diretos continuavam senhores do transporte de cargas. A principal mudança ocorreu na relação com os fregueses, que passaram a lidar com o agenciador e não mais com uma miríade de carregadores individuais. Ademais, a ação desse intermediário limitava-se aos meses de safra. Tal ajuste funcionou como uma espécie de transição entre o carregamento avulso e as transportadoras modernas com sua logística. No entanto, a Agência Duprat deixou de existir na mesma época da petição de Belarmino do Rego Barros, Silva Loyo e Joaquim Antunes. Seu gerente apostou suas fichas em negócios menos sazonais. O empresário francês dedicou-se nos próximos anos à incorporação de uma empresa de construção de edifícios públicos e privados (a Companhia de Edificação) e à redação de O Brasil Agrícola, cuja publicação tornou-se cada vez mais dependente das delongas do orçamento provincial. ${ }^{41}$

Mas a experiência da Agência Duprat deixou suas marcas na atividade carroçável. Ela mostrou aos carregadores e carroceiros que era possível preservá-los no transporte de carga sem grandes rupturas. Deu-lhes noção de pertencimento de grupo com sua divisão de tarefas e sistema de trabalho. Tanto maior esse feito quando se tem em mente a quantidade de carroças empregadas nessa função nas ruas do Recife. Os carregadores autônomos com

38 Estrada de Ferro. O Liberal, Recife, a. IV, n. 62, p. 4, c. 2-3, 28 out. 1864.

39 Tribunal do Commercio. Diário de Pernambuco, Recife, a. XL, n. 224, p. 3, c. 1, 30 set. 1864.

40 Diário de Pernambuco, Recife, a. XLIII, p. 3, c. 2, 6 fev. 1867; Diário de Pernambuco, Recife, a. XLVII, n. 236, p. 3, c. 4,16 de out. 1871.

41 Diário de Pernambuco, Recife, a. XLIX, n. 194, p. 5, c. 2, 24 ago. 1873. Francisco Duprat foi autorizado a fazer a incorporação da Companhia de Edificação pela Lei n. 535, de 20 de junho de 1862, cf. COLLECÇÃO de Leis Provinciaes de Pernambuco do anno de 1862. Pernambuco: Typ. de M. F. de Faria \& Filho, 1862. p. 15-16. 
seus carroceiros passaram, desde então, a responder pela parte do negócio concernente ao recebimento, transporte e distribuição de mercadorias no perímetro compreendido entre o porto e a estrada de ferro. Tudo isso não impediu que os negócios tradicionais fossem mantidos durante a entressafra. Não por acaso, eles falavam em nome de "outra espécie de empresa" nas ações contra a Locomotora. Uma empresa distinta daquela sob a forma de sociedade anônima. Uma empresa formada por relações de confiança, na boa fé das pessoas e com expediente próprio.

A organização do tipo empresarial permitiu que as ações de sabotagem ocorressem de maneira articulada. Seu êxito dependia de uma parceria ou movimento coordenado entre os proprietários e os condutores. Enquanto alguns carros ficavam prostrados na estrada dos armazéns ou seguiam em marcha lenta sobre os trilhos da companhia, outros carroceiros mantinham o serviço normalmente. As práticas de sabotagem sugerem um revezamento cuidadoso para que ninguém fosse prejudicado. Eles precisavam manter a regularidade da circulação de mercadorias e produtos, pois, do contrário, atrairiam para si mesmos a antipatia dos agricultores, comerciantes e demais segmentos. Os insucessos da Locomotora deveriam parecer única e exclusivamente oriundos da sua própria incompetência. Afinal, a empresa tinha carros que viviam dando "prego", contava com um número insuficiente de trabalhadores e não possuía ritmo de trabalho. Todo o resto não passava de uma tentativa de construir um monopólio em detrimento dos senhores de engenho e de "vultos simpáticos e dedicados pais de família, que sustentam luta tão desigual, porque são fracos e a empresa é forte; porque são pobres e a empresa é rica". ${ }^{42}$ Ao condutor direto ou carroceiro pobre só restava abraçar a causa dos carregadores, tornar-se mais um empregado da Locomotora como seus ex-companheiros, ou mudar de profissão.

Por outro lado, as estratégias de reação não se limitaram ao boicote puro e simples. Os carregadores-carroceiros entraram com petições, representações e abaixo-assinados na Assembleia Provincial, na Câmara Municipal e no Governo Provincial contra as propostas de regulamentação das carroças e de elevação dos impostos. Na leitura deles, a diminuição da carga e o aumento do custo da atividade carroçável visava inviabilizá-la economicamente. A excessiva fiscalização da polícia e dos chefes da estação seguia as ordens de Belarmino do Rego Barros. Essas medidas davam provas da existência de um lobby formado por agentes públicos e privados em luta com a "indústria dos carroceiros". Para A Reforma, que fazia oposição na Corte ao governo do barão de Lucena, a concessão da Locomotora encerrava relações clientelistas. O mesmo Belarmino ganhou o privilégio por ser cunhado do ministro do Império, João Alfredo Correia de Oliveira. As relações de parentesco deram-Ihe ainda a capatazia da alfândega, a exploração de minas paraenses e os trapiches alfandegados para os gêneros da Paraíba. Aliás, o ministro beneficiou com cargos públicos outros membros de sua parentela. Seu irmão Joaquim tornou-se juiz substituto da provedoria de Pernambuco, e o de nome Leodegário foi agraciado com o posto de agente fiscal. ${ }^{43}$

42 A Locomotora Pernambucana faltando a suas promessas. A Província, Recife, n. 380, a. II, p. 3. c. 1-2, 29 ago. 1874.

43 A Reforma, Rio de Janeiro, a. VI, n. 171, p. 1, c. 1-5, 31 jul. 1874; A Reforma, Rio de Janeiro, n. 172, a. IV, p. 1, c. 1-2, 1 ago. 1874; A Província, Recife, n. 368, a. III, p. 2, c. 2, 14 ago. 1874. 
O grupo de pressão da Locomotora não queria apenas se sobrepor ao negócio das carroças. O Banco Industrial e Mercantil do Rio de Janeiro prometeu aos acionistas "lucros vantajosos" assim que ela acumulasse o serviço de passageiros com o de cargas. Uma representação chegou a ser dirigida à Assembleia Provincial, na qual se alegou que a Companhia Ferro Carril possuía uma concessão e não um privilégio, o que significava juridicamente que a empresa carecia de exclusividade. A leitura inovadora do contrato soou com uma tentativa de violação de direitos adquiridos e despertou viva oposição na imprensa e na deputação provincial. Mais uma vez, o oficial da Guarda Nacional surgiu como articulador político da Locomotora. O empresário Tito Barcelos tentou minimizar a questão dizendo que o vínculo dele com os novos concessionários terminara com a transmissão da concessão. ${ }^{44}$ No entanto, o que de fato acompanhou o acordo de transferência foi a assinatura de um contrato de prestação de serviço, no qual Belarmino obrigava-se a:

promover perante as autoridades provinciais e municipais tudo quanto for a bem dos interesses da referida empresa, e tudo que for necessário para sua prosperidade, empregando toda sua influência, atividade e esforços a fim de que ela possa ser realizada e mantida sem oposição ou estorvo e se consiga, com presteza e facilidade, o uso dos direitos e favores concedidos pelo contrato com a presidência de Pernambuco e o referido senhor major Belarmino e outros..$^{45}$

\section{O fim da Locomotora}

CARENTE DE UM PRIVILÉGIO EXCLUSIVo, a Locomotora tentou concorrer com as carroças através da redução do frete e do transporte gratuito a seus comitentes. Mas, ao contrário dos carroceiros, a companhia possuía obrigações contratuais. Ela estava obrigada a reparar os desníveis do calçamento e ainda enfrentava alguns conflitos de jurisdição, um deles com a Ferro Carril e outro com o batalhão das Cinco Pontas. Como se não bastasse, uma parte do seu capital estava comprometida com a remuneração do engenheiro fiscal e com a renovação das longarinas de pinho da linha de carris. Concorrendo em condição desigual, a Locomotora não dava lucro aos proprietários, não tinha sede própria e tampouco conseguia honrar seus compromissos contratuais, entre os quais a ampliação da malha férrea para o Afogados e a Passagem da Madalena. A Teixeira, Chaves \& Cia. não suportou os danos financeiros e deixou a concessão nas mãos do Banco Industrial e Mercantil do Rio de Janeiro que, por sua vez, estabeleceu um contrato de arrendamento, em 5 de julho de 1879, com a casa recifense Leite, Osvaldo \& Cia., na razão de dois contos de réis anuais nos dois primeiros anos e outros três contos no quadriênio subsequente. ${ }^{46}$ Embora o montante da transação fosse irrisório ao

44 Diário do Rio de Janeiro, Rio de Janeiro, n. 187, a. 57, p. 2, c. 7, 8 jul. 1874; Jornal do Recife, Recife, a. XVII, n. 71, p. 4, c. 3-5, 28 mar. 1874; Jornal do Recife, Recife, a. XVII, n. 72, p. 5, c. 4-6; p. 6, c. 1, 30 mar. 1874; A Província, Recife, a. III, n. 260, p. 2, c. 1, 5 abr. 1874; Jornal do Recife, Recife, a. XVIII, n. 159, p. 2, c. 6, 16 jul. 1874

45 FUNDAÇÃO BIBLIOTECA NACIONAL. Documentos referentes à ação movida por Belarmino do Rego Barros contra o Banco Industrial e Mercantil do Rio de Janeiro. Recife, 3 de novembro de 1877. Rio de Janeiro: Fundo: I-30, 01, 048, Coleção Figueira de Mello; natureza: manuscrito. 1877.

46 PERNAMBUCO, Governo de. (1879-1880: Albuquerque). Falla com que o Exm. ${ }^{\circ}$ Sr. Dr. Lourenço Cavalcanti de Albuquerque abrio a sessão da Assembléa Provincial de Pernambuco no dia $1^{\circ}$ de março de 1880. Pernambuco: Typ. de Manoel de Figueiroa de Faria \& Filhos, 1880. p. 23-24. 
tipo de negócio, os arrendatários suspenderam as operações no ano seguinte e entraram em litígio com os concessionários. É que o banco carioca omitiu dos novos arrendatários que o terreno da cocheira fora cedido à empresa a título precário. Ocorre que os empresários investiram na reforma do edifício e desconheciam a preferência da ferrovia do São Francisco sobre a área vizinha à estação de Cinco Pontas. ${ }^{47}$

Após tantos atropelos e a suspensão do tráfego, o governo da província seguiu a opinião do procurador dos feitos da Fazenda e determinou o término imediato do contrato, dando o prazo de três meses para a retirada dos trilhos e a recomposição do calçamento. A instituição bancária apelou para utilidade pública do empreendimento e obteve do mesmo governo seis meses de recuperação empresarial. Em 20 de julho de 1882, o presidente renovou o contrato com o banco. Uma sociedade anônima assumiu a direção da empresa, em 1884, sendo seus representantes José da Silva Loio Jr., Leal \& Irmãos, Souza Pinheiro \& C., Tavares de Mello \& Genros, Jovino Bandeira e Antônio José Leopoldino Arantes. ${ }^{48}$

A despeito da experiência deles e de pertencerem ao quadro social da Associação Comercial de Pernambuco, o balanço geral da Locomotora foi invariavelmente negativo. Ela acumulou um déficit progressivo em parte oriundo de um empréstimo, da anualidade bancária e dos impostos provinciais. Em 1886, a comissão fiscal da Locomotora concluiu que se o ritmo permanecesse o mesmo, os acionistas veriam "em breve totalmente absorvido o capital da companhia". ${ }^{49}$ Foi o que aconteceu na prática. O relatório do engenheiro fiscal relativo ao exercício 1887-1888 demonstrou que o "estado financeiro da empresa é desanimador", em decorrência da progressão dos déficits anuais e da concorrência desleal dos donos de carroças, que "vendo na empresa somente um rival tratam de embaraçar o expediente desta, já demorando ou descarregando sobre seus trilhos, já propositalmente ocasionando acidentes nas carroças sobre a própria linha onde transitam os carros da empresa". ${ }^{50}$

O que animou os diferentes arrendatários da Locomotora era a possibilidade de fechar um acordo de exclusividade com as ferrovias, e com isso conquistar o mercado das carroças. Mas a Estrada de Ferro do São Francisco visando reduzir o custo do frete preservou o clima de competição. Seu desinteresse em celebrar alguma parceria com ela é notório no acordo firmado em 1885. Nenhuma das cláusulas contratuais beneficiava a transportadora em particular. Ao contrário, a empresa assumiu a obrigação de executar obras na entrada da estação, conservar o calçamento em toda a malha férrea e remover seus trilhos das Cinco Pontas. A Locomotora ainda renunciou a possíveis indenizações e a recorrer a instâncias judiciais em caso de conflito. O mais curioso é que o transporte de cargas permaneceria "em concorrência com as carroças de outros indivíduos particulares". ${ }^{51} \mathrm{Em}$ se tratando das demais

47 PERNAMBUCO, Governo de. (1881-1882: Correia). Falla com que o Exm. ${ }^{\circ}$ Sr. Dr. Antonio Epaminondas de Barros Correia $1^{\circ}$ vice-presidente da provincia abrio a sessão da Assemblea Legislativa de Pernambuco em $1^{\circ}$ de março de 1882. Pernambuco: Typographia de M. Figueiroa de Faria \& Filhos, 1882. p. 43-44.

48 PERNAMBUCO, Governo de. (1885-1886: Pereira Jr.). Falla que o presidente da provincia conselheiro José Fernandes da Costa Pereira Junior dirigio á Assemblea Legislativa de Pernambuco no dia de sua instalação, a 6 de março de 1886. Recife: Typ. Manoel Figueroa de Faria \& Filhos, 1886. p. 49.

49 Balanço geral da companhia Locomotora Pernambucana, em 31 de agosto de 1886. Jornal do Recife, Recife, n. 282, a. XXIX, p. 2, c. 6,8 dez. 1886.

50 APEJE. Fiscalização da Empreza Locomotora Pernambucana. Recife, 28 de agosto de 1888. Recife: Fundo; Companhias Diversas, D-II, natureza: manuscritos, fls. 506-507. 1888.

51 PERNAMBUCO, Governo de. (1885: Leão). Falla com que o Exm. ${ }^{\circ}$ Sr. terceiro vice-presidente Dr. Augusto de Souza Leão abrio a sessão da Assembléa Legislativa Provincial de Pernambuco a $1^{\circ}$ de março de 1885. Recife: Typ. de Manoel Figueiroa \& Filhos, 1885. p. 12. 
ferrovias, a distância entre o anúncio das obras e a inauguração do tráfego não chegou a tempo de amenizar os déficits acumulados. Tanto a estrada de ferro do Limoeiro como a de Caruaru só entraram em operação nos anos de 1880 por seções parciais. A primeira só atingiu sua estação terminal no final do Império e a segunda no regime republicano. ${ }^{52}$

A ligação direta entre as estações ferroviárias e o porto através da Locomotora acabou oficialmente em 1890. Sua decadência pôde ser expressa pela extensão férrea e pelo número de volumes transportados. No esplendor, a Locomotora operava com $8.565 \mathrm{~km}$ de extensão. Ela transportou das Cinco Pontas até o porto e vice-versa 256.465 sacos de açúcar, 4.545 de algodão, 281 peças de couro, 1.820 cascos de aguardente e 59.378 volumes diversos, perfazendo um superávit de 1:030\$930 (um conto) réis. Em 1885, a extensão da via reduziu-se a 6.208 km e limitou-se a ligar as estações centrais das três ferrovias da província ao cais do porto. No exercício 1884-1885, os carros da Locomotora transportaram um total de 224.928 unidades, das quais 114.287 vieram da estação central do Limoeiro e dos trapiches do Bairro do Recife e o restante da ferrovia do São Francisco, ou seja, 97.561 volumes a menos do que em 1876. A malha diminuiu ainda mais no exercício de 1887-1888. A empresa operava com a metade do início da concessão $(4.773 \mathrm{~km})$. Ainda que o número de itens transportados fosse semelhante ao auge da companhia (306.382 volumes), a redução do valor do frete para atrair novos fregueses e os déficits anteriores levaram a empresa à falência. ${ }^{53}$

O tipo de custo gerado pelo uso de carroças ou carros da Locomotora chamava-se, na época, "despesa de distribuição". Ela era diretamente proporcional ao trajeto percorrido pelo produto e variava segundo as estratégias dos transportadores. Quando a concorrência restringia-se aos carroceiros, os preços do frete de açúcar entre a estação de Cinco Pontas e o porto eram de 200 réis. Em 1874, a Teixeira, Chaves \& Cia. definiu o valor do carreto para o mesmo percurso em 120 réis por saco de açúcar, 160 réis por fardo de algodão e $2 \$ 000$ réis por pipa de âncoras ou barris. Já as tarifas na zona exclusivamente portuária custavam 80 réis por saco de açúcar, 100 réis por fardo de algodão e $1 \$ 300$ réis por pipa de âncoras ou barris. No carreto estavam incluídas todas as operações de carga, descarga e arrumação nos armazéns. A Locomotora ainda oferecia transporte gratuito aos fregueses da empresa até a estação da São Francisco ou aos que enviassem mercadorias para os bairros do Recife e de Santo Antônio. Essa tabela de preços ficava abaixo do frete dos carroceiros e dava aos agricultores uma economia anual de 60 contos de réis. ${ }^{54} \mathrm{Em}$ razão dos motivos citados, a Teixeira, Chaves \& Cia. e os arrendatários posteriores não sustentaram os valores pré-fixados e entraram em descrédito público. Muito contribuiu para manchar a reputação da Locomotora os ataques sistemáticos dos carroceiros na imprensa.

A Leite, Osvaldo \& Cia. usou o mesmo expediente dos seus predecessores. A casa comercial reduziu o valor do carreto na seção que ia da estação de Cinco Pontas até o Recife, e na que vinha desde os trapiches do Forte do Matos até as ruas do Brum e do Apolo. A redução foi vista como uma estratégia para retomar a atividade da empresa, que fora suspensa desde a saída dos antigos empresários. Os carroceiros disseram na imprensa que a diminuição dos

52 PINTO, op. cit. p. 85 e 104.

53 APEJE. Fiscalização da Empreza Locomotora Pernambucana. Recife, 28 de agosto de 1888. Recife: Fundo; Companhias Diversas, D-II, natureza: manuscritos, fls. 456-457 e 506-507.1888.

54 Locomotora Pernambucana. A Província, Recife, n. 364, a. II, p. 4, c. 3, 9 ago. 1874; Locomotora Pernambucana. Jornal do Recife, Recife, n. 240, a. XVII, p. 2, c. 4, 22 out. 1874. 
fretes não passava de uma tática antiga visando o monopólio sobre o transporte de cargas. Não sabemos se eles estavam certos. O que não resta dúvida é que a Locomotora não se tornou a "preferida para a condução dos ditos gêneros" e precisou retomar a tabela anterior, ou seja, 200 réis para o transporte de cada saca de açúcar, algodão e pipa de aguardente entre o Recife e a estação central da Recife a São Francisco; e 100 réis por saco de açúcar entre os trapiches e os armazéns do bairro portuário. ${ }^{55} \mathrm{~A}$ partir daí, não diminuiu mais sua tabela de preços até a derrocada da empresa no final do Segundo Reinado. Há quem temesse daí a elevação do preço e a volta do transporte do açúcar ao modo "absolutamente imundo e prejudicial" ${ }^{56}$

Recebido em 21/08/2019

Aprovado em 20/03/2020

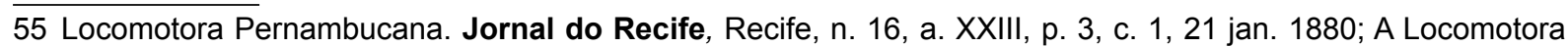
e a polícia. Jornal do Recife, Recife, n. 17, a. XXIII, p. 2, c. 4, 22 jan. 1880; Empreza Locomotora. Jornal do Recife, Recife, n. 27, a. XXIV, p. 3, c. 3, 4 fev. 1881.

56 Algumas considerações sobre as sociedades anonymas existentes nesta provincia. Jornal do Recife, Recife, n. 141 , a. XXX, p. 2, c. 7,23 jun. 1887. 